\title{
An Analysis of the Essential Structure of Entrepreneurial Culture*
}

\author{
Guang $\mathrm{Yu}$ \\ Baicheng Normal University \\ Baicheng, China
}

\begin{abstract}
Entrepreneurial culture is a special cultural pattern formed by entrepreneurs in entrepreneurial practices. Entrepreneurial culture is a system with a rigorous organizational structure. From the perspective of cultural spatial stratification, entrepreneurial culture can be divided into deep entrepreneurial spirit culture, middle entrepreneurial system culture, shallow entrepreneurial behavior culture and surface entrepreneurial material culture. These four parts interact and are closely connected, influencing the development of entrepreneurial culture in different ways and forming an inseparable organic whole.
\end{abstract}

Keywords-entrepreneurship; entrepreneurial culture; essential structure

\section{INTRODUCTION}

Entrepreneurial culture is an important part of the complete system of culture. It is a system with a rigorous organizational structure. From the perspective of cultural spatial stratification, entrepreneurial culture can be divided into deep entrepreneurial spirit culture, middle-level entrepreneurial system culture, shallow entrepreneurial behavior culture and superficial entrepreneurial material culture. These four parts interact and are closely connected, influencing the development of entrepreneurial culture in different ways and forming an inseparable organic whole.

\section{ENTREPRENEURIAL MATERIAL CULTURE IS THE FOUNDATION OF ENTREPRENEURIAL CULTURE}

\section{A. Entrepreneurial Material Culture Provides Material Basis for the Development of Entrepreneurial Culture}

The material achievements created by the entrepreneurial material culture are developed on the basis of the material civilization achievements created by predecessors, and at the same time, a richer material culture is created with a higher level of modern technology. This is a rising development process that keeps pace with times. The great improvement of material culture, as a prerequisite for the development of entrepreneurial culture, provides a specific and necessary material basis and material environment for the practical

*Fund: This paper is the phased achievement of the 13th Five-year Social Science Research Project of the Jilin Provincial Department of Education; Research on the philosophical implication of contemporary entrepreneurial culture; Research on the development outlook of contemporary entrepreneurial culture. activities of entrepreneurial subjects. Entrepreneurial material culture has its own material basis and power Entrepreneurial culture defines the technical tools and the level of awareness that entrepreneurs can use. Entrepreneurs take entrepreneurial material culture as the foundation and dependence of entrepreneurial development. Entrepreneurs make full use of existing material forces to study the internal laws of entrepreneurship. This can enable entrepreneurs to break through the existing level of material development and create a higher material culture of entrepreneurship. This will form a virtuous cycle of entrepreneurial material and cultural development.

\section{B. Entrepreneurial Material Culture Is the Forerunner of Entrepreneurial Culture Development}

The essence and connotation of entrepreneurial culture are abstractly extracted from entrepreneurial practices, and its objective existence cannot be denied. However, it can't be seen or touched. People's most real contact with it is through its material carrier, namely, entrepreneurial material culture. The development of entrepreneurial culture always manifests itself in certain material phenomena. The level and development status of entrepreneurial culture of a society can always find some clues and answers through the existence of material forms such as material products and achievements. Entrepreneurial material culture in the entrepreneurial culture, the surface layer, the outermost layers of the interpretation of it become deeply grasp the starting point of entrepreneurial culture and important entrance, because people know this is a process from surface to deep process, from the surface of entrepreneurial culture to analyze the entrepreneurial culture, can step by step, to fully understand the entrepreneurial culture as a whole, gradually understand its core spirit, know the entrepreneurial culture and identity for the people provides the necessary channels and opportunities.

\section{ENTREPRENEURSHIP CULTURE IS THE ESSENCE OF ENTREPRENEURSHIP CULTURE}

\section{A. Entrepreneurial Spirit Culture Promotes the Development of Entrepreneurial Material Culture}

Entrepreneurial spirit culture really shows its life characteristics as a culture, which is vividly presented in the way of the internal development impetus of entrepreneurial material culture. Human development has two basic needs: 
one is material needs, which is the premise and basic conditions of human survival; the other one is spiritual needs, which is the fundamental symbol of human beings. Matter lays the foundation for spiritual development, and spirit provides intellectual support for material development and inner power for human production practice. At present, entrepreneurial spirit culture has increasingly become the cohesion of entrepreneurial practice and an important source of entrepreneurial production creativity, as well as an important spiritual pillar of entrepreneurial subjects' life, playing an increasingly important role in promoting the development of entrepreneurial material culture.

\section{B. Entrepreneurial Spirit Culture Prescribes the Basic Trend of Entrepreneurial System Culture}

As an important carrier of carrying and spreading entrepreneurial spirit culture, the development direction of entrepreneurial system culture is consistent with spiritual culture, which is guided and restricted by spiritual culture. Entrepreneurial culture is always the change of objective environment and conditions for entrepreneurship development and rapid response, strong sensitivity to social development. With the development of entrepreneurship material basis and the profound changes of social environment, the existing system of entrepreneurial culture appears more and more lagging behind the development and changes, leading in an entrepreneurial culture and creating a new spirit and public opinion atmosphere. Under the influence of the reform and development of the system culture are greatly needed, it is imperative that a new system of entrepreneurship culture is in such a powerful spirit culture under the action of stress and arises at the historic moment. Therefore, entrepreneurial system culture should closely follow the development pace of spiritual culture, take the connotation of entrepreneurial spirit culture as its core concept, in order to accurately position its own development direction, adapt to the new requirements of entrepreneurial era, maintain the order of entrepreneurial development, and consolidate the development results.

\section{Entrepreneurial Spirit Culture Is the Promotion of Entrepreneurial Behavior Culture}

The spiritual level and state of the entrepreneur are naturally closely related to the entrepreneurial behavior culture. The entrepreneurial spirit culture determines and influences the formation and development of the behavioral culture. Entrepreneurial spirit culture is the unremitting pursuit of the ideal state of life. Entrepreneurial spirit culture will promote the overall development of entrepreneurial subjects as an important task. Entrepreneurial spirit culture internalizes advanced spiritual ideas into the thinking of entrepreneurial subjects through education. This can improve the behavior level of the entrepreneurial subject and guide the entrepreneurial behavior to have more cultural charm and spiritual connotation. Entrepreneurial spirit culture dominates the thinking direction and ideal pursuit of entrepreneurial behavior subject. Entrepreneurial spirit culture can cultivate the cultural accomplishment and behavior habit of the entrepreneurial behavior subject. This can promote the behavior quality and cultural taste of the subject.

\section{ENTREPRENEURIAL SYSTEM CULTURE IS THE GUARANTEE OF ENTREPRENEURIAL CULTURE}

\section{A. Entrepreneurial Culture Standardizes the Basic Order System of Entrepreneurial Culture}

Entrepreneurial activities require an orderly and stable environment. As a carrier to provide order, system becomes indispensable in the whole entrepreneurial system. Entrepreneurial culture is the institutional embodiment of entrepreneurial culture ideas. Entrepreneurial system culture is the norm of the basic order of entrepreneurial culture. Entrepreneurial culture is the institutional guarantee for the steady cultivation of entrepreneurial culture. In fact, without various norms and guidance of entrepreneurial culture, it is impossible to have a stable and orderly entrepreneurial environment and practical vitality. Entrepreneurial culture not only standardizes and guides the behaviors of entrepreneurial groups and corrects their wrong values, but also can mobilize the initiative and creativity of entrepreneurs and stimulate the vitality of entrepreneurial practice.

\section{B. Entrepreneurial Culture Is an Important Carrier of Entrepreneurial Culture Communication}

The entrepreneurial system is the criterion for the interaction between entrepreneurial subjects and external things. Entrepreneurial system contains the understanding of entrepreneurial subject to the system itself. The entrepreneurial system embodies the value and significance of culture. The cultural characteristics and inner spirit of entrepreneurial culture are reflected in the construction and arrangement of the system. Entrepreneurial culture forms a relatively stable entrepreneurial culture atmosphere with the implementation of entrepreneurial system and innovates the spirit of entrepreneurial culture. The formation of entrepreneurial system comes from entrepreneurial practice and entrepreneurial cultural environment. Entrepreneurial culture links institutions to the environment. Entrepreneurial culture unifies people's entrepreneurial behaviors and values. Entrepreneurial system culture connects entrepreneurial culture with the outside world. The entrepreneurial culture exchanges and transmits the spirit and idea of entrepreneurial culture, and unifies the system and culture according to the cultural identification of common values. When entrepreneurial culture is embodied as the carrier of entrepreneurial culture communication, it reflects and disseminates the value and spirit of entrepreneurial culture in certain form. 


\section{ENTREPRENEURIAL BEHAVIOR CUlture IS THE EXTERNAL MANIFESTATION OF ENTREPRENEURIAL CULTURE}

\section{A. Entrepreneurial Behavior Is the Practice of Entrepreneurial Cultural Value}

Entrepreneurial behavior refers to the specific entrepreneurial behavior activities of the entrepreneurial subject. Entrepreneurial behavior includes entrepreneurial planning, entrepreneurial decision-making, entrepreneurial management and other contents. The prosperity of entrepreneurship brings about the vigorous development of the whole society. Entrepreneurship is not only a means of livelihood, but also a choice of entrepreneurial behavior to meet the needs of their own development. Any entrepreneurial behavior reflects and represents an entrepreneurial culture. Entrepreneurial behavior is the expression and practice of entrepreneurial culture. In the practice of entrepreneurial behavior, entrepreneurial subjects not only gradually create a channel for them to realize the ideal and value of life, but also guide the realization of personal achievements with the new entrepreneurial culture spirit. Entrepreneurial behavior injects new industrial strength and vigorous spiritual power into the society. All kinds of material and spiritual products produced by entrepreneurs' entrepreneurial activities can further promote the transformation of production mode and promote the formation and development of entrepreneurial society.

\section{B. Entrepreneurship Propaganda Is the Representation of the Connotation of Entrepreneurship Culture}

Entrepreneurship propaganda is the most direct means to popularize the basic spirit of entrepreneurship culture. Entrepreneurship propaganda is a very important part of entrepreneurship. We can cultivate the public awareness of entrepreneurship and create a good entrepreneurial atmosphere through entrepreneurship propaganda. The ways of entrepreneurship publicity include cultural communication, family edification, and behavior practice and so on. Entrepreneurial advocacy represents and presents the content and requirements of entrepreneurial culture. Entrepreneurship publicity can fully display the value connotation of entrepreneurship culture in the content and link of publicity, so that people form entrepreneurial consciousness and entrepreneurial behavior. Entrepreneurship propaganda plays an important role in cultivating and establishing entrepreneurship awareness. Entrepreneurship propaganda can not only reflect entrepreneurship culture and its value orientation, but also enable people to understand the concept and requirements of entrepreneurship culture. This can form the general entrepreneurship consciousness and concept in the whole society.

\section{CONCLUSION}

In short, as the essence of entrepreneurial culture, deep culture plays a decisive role in determining the development direction of other parts of entrepreneurial culture. Middlelevel culture and shallow culture are respectively the guarantee and explicit of entrepreneurial culture and the embodiment of entrepreneurial spirit culture. Surface culture is the foundation and premise of entrepreneurial culture and has an important influence on the formation and development of other parts. These four parts interact and are closely connected, influencing the development of entrepreneurial culture in different ways and forming an inseparable organic whole.

\section{REFERENCES}

[1] Gareth Morgan. Creative Organization Theory. A Resource Book, SAGE Publications Ltd. 1989.

[2] Tony Proctor. The Essence of Manageme. Creativity. Prentice Hall Europe, 1995.

[3] Lee Roy Beach. Making The Right Decision. Organizational Culture, Vision, and Planning, Prentice Hall, 1993.

[4] Peter Drucker. Innovation and Entrepreneurship. Practice and Principles, Harper\&Row, 1985

[5] March J G. Exploration and exploitation in organizational learning [J] Organization Science, 1991(2) 